\title{
The impact of a Czech nuclear power plant operation on the VItava River radioactivity
}

\author{
M. Švadlenková ${ }^{1}$ and E. Hanslík ${ }^{2}$ \\ ${ }^{1}$ University of South Bohemia, Dept. of Physics, Jeronýmova 10, 37115 České Budějovice, \\ Czech Republic, e-mail: maja@jcu.cz \\ ${ }^{2}$ T.G. Masaryk Water Research Institute, Podbabská 30, 16062 Praha 6, Czech Republic, \\ e-mail: Eduard_Hanslik@vuv.cz
}

\begin{abstract}
In this contribution, the results of the radioactivity bio-monitoring of the Vltava River before (1996-2000) and after (2000-2003) the start-up of the PWR-type South Bohemian nuclear power plant are presented. The liquid radioactive effluents are discharged into the Vltava River, which also serves as a source of drinking water intended for Prague. The bio-monitoring was made by means of water plants and freshwater bivalve that are found along the watercourse. Biological samples were processed and then the activity of natural and man-made radionuclides was assessed by gamma-spectrometry. The analysed statistical data did not prove any impact of the three years NPP operation on the Vltava River radioactivity.
\end{abstract}

\section{INTRODUCTION}

The hydrosphere radioactive pollution monitoring aiming at the assessment of the impact of nuclear power plants fuel cycle often demands high detection sensitivity of measuring instruments, because of relatively low activity levels of natural and man-made radionuclides. The suitable bioindicators, which highly accumulate certain radionuclides in their biomass, can facilitate the radionuclide identification and the water radioactivity determination.

Water plants are the suitable tool for the radioactivity monitoring of hydrosphere $[1,2,3]$. Their accumulation capacity depends above all on the radionuclide type and the plant species, but also on the radionuclide speciation, the vegetation period of plant, the activity concentration of water and its time course, the mineral composition, $\mathrm{pH}$, temperature and other water qualities, and so on. Bioaccumulation factor values related to dry weight of hydrobionts are of order ranging from $10^{1}$ to $10^{5}$. Freshwater bivalves are suitable especially for long-term bioindication of the presence of some man-made radioisotopes $(\mathrm{Mn}, \mathrm{Sr}, \mathrm{Co}, \mathrm{Cs}$, I, etc.) in rivers and reservoirs.

The low-level radioactive releases from the PWR-type, 2x1000 $\mathrm{MW}_{\mathrm{e}}$ nuclear power plant (NPP) in Temelin (South Bohemia, Czech Rep.) are discharged after their processing into the Vltava River at Kořensko locality. The radioactivity of chosen river hydrobionts occurring above and below the discharge point was investigated.

\section{MATERIALS AND METHODS}

\subsection{Investigated localities and hydrobionts}

Aquatic plants were sampled at five localities along the Vltava River stream. Distance between the first and the last locality is about $150 \mathrm{~km}$. The first locality (Hněvkovice) is the reference one, because it is not influenced by the radioactive liquid releases from the NPP. Bivalves were sampled at the valley reservoir (Orlík) on the Vltava River. 
The main sampled and analysed water plants can be divided into four groups: water mosses (Hygrohypnum ochraceum, Fontinalis antipyretica), algae (Oedogonium sp., Microspora sp.), other submerged plants (Batrachium sp., Myriophyllum spicatum) and riverbank plants (Glyceria maxima, Phalaris arundinacea, Polygonum hydropiper). Anodonta cygnea is the freshwater bivalve species.

\subsection{Procedure}

Sampling was made once or twice per year at each locality; the riverbank plants were sampled without roots. The plants and the bivalves were washed carefully in the river water to remove the possible suspension layer on their surface. As to the bivalves, soft tissue and shell were treated separately. Samples were dried at $105^{\circ} \mathrm{C}$ to constant weight and then homogenised.

Radioactivity measurement was made by means of semiconductor gamma-spectrometry with a HPGe detector [4]. The samples were placed in plastic bottles of 0.5 litter (Marinelli bottles) or 0.2 litter volume. Measuring period was about 30 hours.

Mathematica 4.1 (Wolfram Research) software was used for the statistical data analysis.

\section{RESULTS AND DISCUSSION}

\subsection{Natural radionuclides}

The magnitude and the distribution of the mean values belong to specific activities of natural radionuclides in the hydrobionts after the NPP start-up did not change in comparison with the situation before the start-up. The mean activities for the whole observation period (1996-2003) of four chosen natural radionuclides in water mosses, riverbank plants (mean for reeds and knotweed) and bivalve are represented on figure 1 .

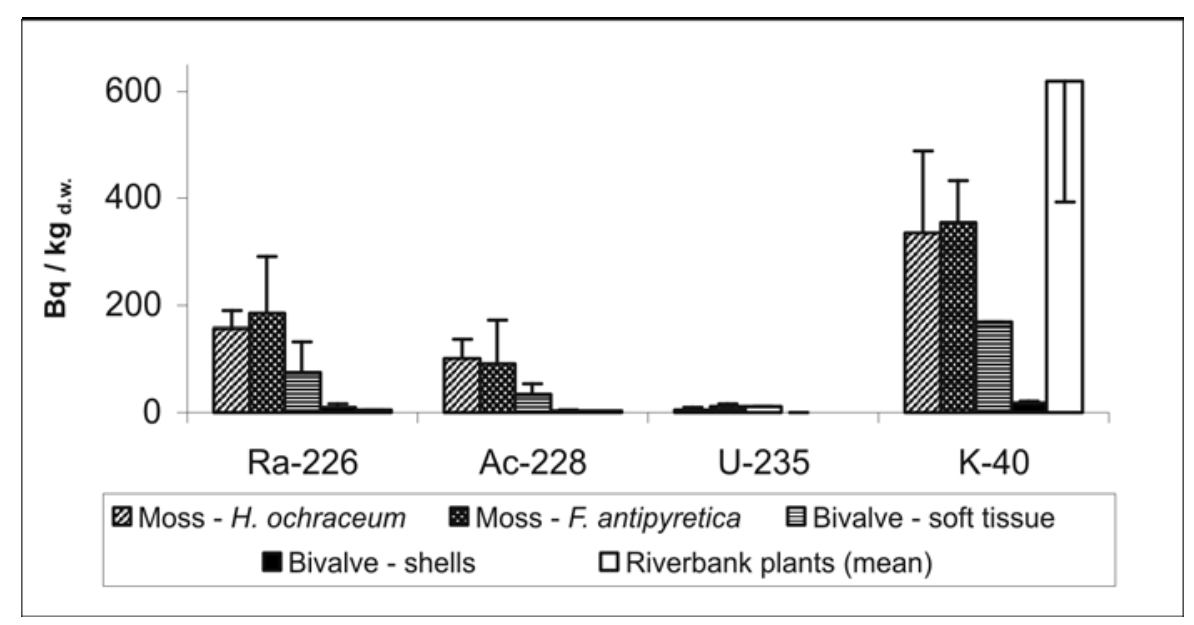

Figure 1. Distribution of natural radionuclide activities in water mosses, bivalve Anodonta cygnea and riverbank plants (mean for three species). Columns represent the mean values during 1996-2003 \pm S.D. of 8 to 12 analysis.

\subsection{Man-made radionuclides}

${ }^{137} \mathrm{Cs}$ is the only man-made radionuclide the hydrobiont specific activity values of which were largely above the lower limit of detection at the $95 \%$ confidence level (CL). This radionuclide originates from nuclear weapon tests and nuclear accidents (especially the Chernobyl's one). 
The statistical analysis of our data does not reject at the 95\% CL the hypothesis of equal temporal trend of the ${ }^{137} \mathrm{Cs}$ hydrobiont specific activities before and after start-up of the Temelín NPP. Consequently, the NPP impact on the hydrobionts activity in Vltava River was not proved.

The values of ${ }^{137} \mathrm{Cs}$ specific activities in hydrobionts show a decreasing trend during the whole observed time period. Meanwhile, owing to the relatively small number of data and the low values of hydrobiont activities, the decreasing temporal trend of ${ }^{137} \mathrm{Cs}$ was not statistically proved at the $95 \% \mathrm{CL}$. It was proved for the water mosses and the riverbank plants at a lower CL. The ${ }^{137} \mathrm{Cs}$ activity decrease parameters of the three water plant types is shown at table 1. The activity decrease is often characterised by the effective half-life, which takes note of physical and ecological (biological) half-lifes. The effective half-life, $T_{\text {eff }}$, equals the quotient $\ln 2 / \lambda_{\text {eff }}$, where $\lambda_{\text {eff }}$ is the slope of logarithm of ${ }^{137} \mathrm{Cs}$ activity concentration corrected for physical decay $\mathrm{T}_{1 / 2}$. The ecological half-life, $\mathrm{T}_{\text {ecol }}$, is defined by the formula: $\left(\mathrm{T}_{\text {ecol }}\right)^{-1}=\left(\mathrm{T}_{\text {eff }}\right)^{-1}-\left(\mathrm{T}_{1 / 2}\right)^{-1}$. The respective CL of $\lambda_{\text {eff }}$ is also indicated in the table 1 . The value of $\mathrm{T}_{\text {eff }} \approx 4$ years can be taken as the statistically more plausible one. As to the bivalve, the temporal radioactivity decrease was not statistically proved.

Let us compare the ${ }^{137} \mathrm{Cs}$ activity temporal trend in the hydrobionts and other compartments of the Vltava River, that is the water and the bed sediment [5]. The water activity concentration fluctuates round a mean value, which slightly differs for various localities and it ranges from 1 to $3 \mathrm{mBq} \cdot \mathrm{l}^{-1}$. In contrast, at majority of localities the sediment specific activity shows the statistically significant decrease with the mean effective half-life about 4 years, which is similar to the effective half-life of the water plants.

Table 1. Ecological $\left(\mathrm{T}_{\text {ecol }}\right)$ and effective $\left(\mathrm{T}_{\text {eff }}\right)$ half-life of ${ }^{137} \mathrm{Cs}$ activity decrease for water mosses (two species) and riverbank plants (mean of three species from five localities). $n=$ number of analysed samples; $\lambda_{\text {eff }}=$ activity decrease constant - see the text; $\mathrm{SE}=$ standard error of $\lambda_{\text {eff; }}$ CL $=$ confidence level.

\begin{tabular}{|llcccccc|}
\hline Hydrobiont & Locality & $\mathbf{n}$ & $\boldsymbol{\lambda}_{\text {eff }}\left(\mathbf{y}^{-\mathbf{1}}\right)$ & $\mathbf{S E}\left(\mathbf{y}^{\mathbf{- 1}}\right)$ & $\mathbf{C L}(\mathbf{\%})$ & $\mathbf{T}_{\text {eff }}(\mathbf{y})$ & $\mathbf{T}_{\text {ecol }}(\mathbf{y})$ \\
\hline Fontinalis antipyretica & Šěchovice & 7 & 0,18 & 0,08 & 92 & 3,9 & 4,5 \\
Riverbank plants (3 species) & 5 localities & 25 & 0,15 & 0,09 & 87 & 4,6 & 5,5 \\
Hygrohypnum ochraceum & Hněvkovice & 7 & 0,07 & 0,07 & 63 & 9,9 & 14,7 \\
\hline
\end{tabular}
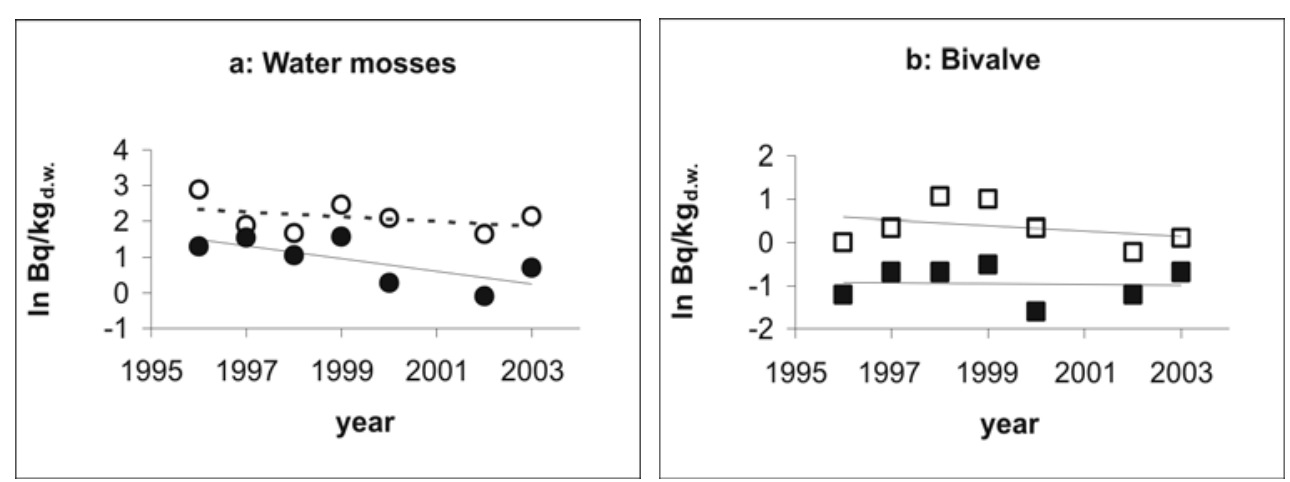

Figure 2. Temporal trend of ${ }^{137} \mathrm{Cs}$ in water mosses and bivalve. a: -- --- Hygrohypnum - reference locality, -- Fontinalis - near Prague locality; b: --口-- Anodonta - soft tissue, —- - Anodonta - shells.

The ${ }^{137} \mathrm{Cs}$ bioaccumulation factor $(\mathrm{BF})$ can be assessed as the quotient of hydrobiont specific activity $\left(\mathrm{Bq} \cdot \mathrm{kg}^{-1}\right)$ and mean water activity concentration $\left(\mathrm{Bq} . \mathrm{l}^{-1}\right)$. Thus, e.g. for the moss Fontinalis antipyretica $\mathrm{BF} \approx 1300$ and for Hygrohypnum ochraceum $\mathrm{BF} \approx 6000$ (related to dry weight). The first one agrees with published data - e.g. [6], while the published data for Hygrohypnum sp. were not found by the authors.

The mean ${ }^{137} \mathrm{Cs}$ specific activity distribution among various types of hydrobionts for the period 
before and after the NPP start-up is shown at table 2 and on figure 3. It can be seen that the relative ${ }^{137} \mathrm{Cs}$ distribution was not influenced by the NPP operation.

Table 2. Relative distribution of the mean ${ }^{137} \mathrm{Cs}$ activity in chosen hydrobionts for the period before and after the NPP start-up. $\mathrm{s}=1 \sigma$-standard error of arithmetic mean value $(\%) ; \mathrm{n}=$ number of analysed samples.

\begin{tabular}{|l|c|c|c|c|c|c|}
\hline Measuring period $\rightarrow$ & \multicolumn{3}{|c|}{ Before NPP operation } & \multicolumn{3}{c|}{ After NPP start-up } \\
\hline Hydrobiont $\downarrow$ & $\mathbf{\%}$ & $\mathbf{~ s ~ ( \% ) ~}$ & $\mathbf{n}$ & $\mathbf{\%}$ & $\mathbf{~ s ~ ( \% ) ~}$ & $\mathbf{n}$ \\
\hline Bivalve - shells & 3,8 & 1,1 & 8 & 4,3 & 2,1 & 3 \\
\hline Bivalve - soft tissue & 16,2 & 5,5 & 8 & 14,2 & 3,4 & 3 \\
\hline Riverbank plants & 29,2 & 20,1 & 25 & 26,0 & 19,6 & 21 \\
\hline Water mosses & 50,9 & 34,3 & 10 & 55,6 & 38,4 & 6 \\
\hline
\end{tabular}

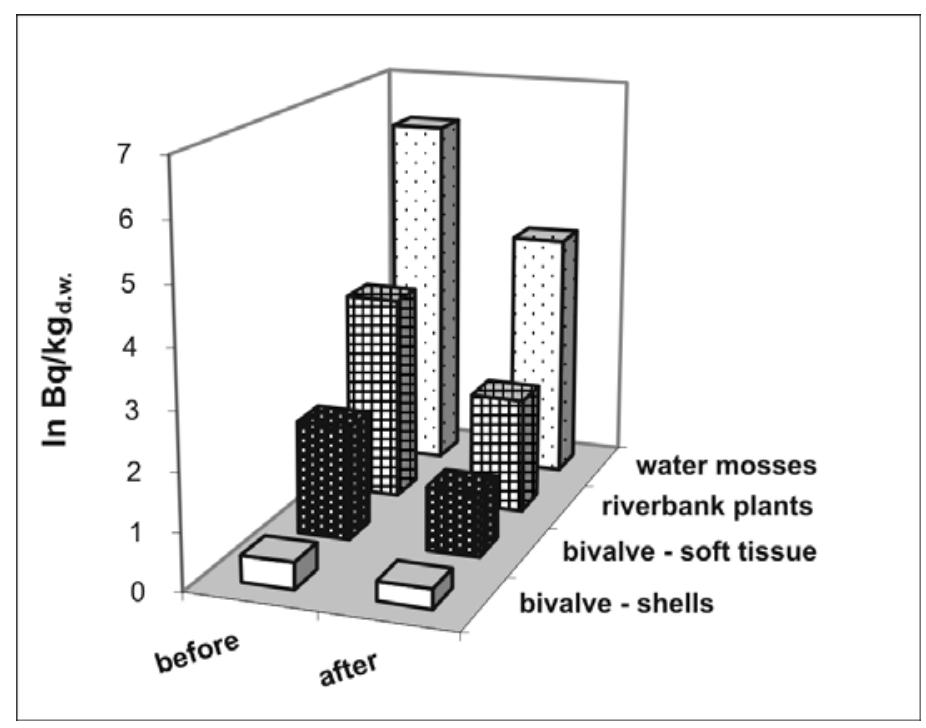

Figure 3. Distribution of ${ }^{137} \mathrm{Cs}$ specific activity in hydrobionts before and after the nuclear power plant start-up.

\section{CONCLUSIONS}

The statistical data analysis did not prove any impact of the three years Temelín NPP operation on the radioactivity of investigated hydrobionts from the Vltava River.

The radionuclides activity values of hydrobionts are often near the low detection level (except of ${ }^{40} \mathrm{~K}$ ) and they show a large dispersion for individual species.

The biomonitoring is a suitable complementary method of the radioactivity monitoring in hydrosphere.

\section{Acknowledgements}

This work was supported by grant from the T. G. Masaryk Water Research Institute of Prague and by grant ME419 from the Czech Ministry of Education, Youth and Sports.

The authors appreciate the kind help of Zdeněk Zídek - manager of the Orlik dam and divers Libor Cimburek j. 
and Jana and Jan Zemans with the bivalves sampling. We thank also to Tomáš Mrkvička (Dept. of Mathematics, South Bohemian University) for the Mathematica software support and Michal Šerý (Dept. of Physics, South Bohemian University) for the graphical arrangement of this contribution.

\section{References}

[1] Pally M. and Foulquier L., La capacité et les modalitées de la fixation du radiocesium par les vegetaux aquatiques. CEA-BIB-235, C20, Paris, CEN Cadarache, (1981) 255 pp.

[2] Švadlenková M., Dvořák Z. and Slávik O. Internat. Revue der Gesamten Hydrobiologie, 74 (4) (1989) 461-469.

[3] Beaugelin-Seiller K., Caracterisation de mousses dulçaquicoles comme indicateurs de contamina tion radioactive. Rapport CEA-R-5697, IPSN, CE Cadarache, France, (1995).

[4] CSN ISO 10703 (75 7630): Water quality - Determination of the activity concentration of radionuclides by high resolution gamma-ray spectrometry. Czech Standard Institute, 1999.

[5] Hanslík E. and Ivanovová, D.: Monitoring and assessment of qualitative and quantitative parameters in water and river bottom sediments in selected river profiles and reservoirs. Report $\mathrm{T}$. G. M. WRI Prague, 2004 (in Czech).

[6] Vanderploeg H.A., Bioaccumulation Factors for Radionuclides in Freshwater Biota. Oak Ridge Nat. Lab., Environ. Sci. Div. Public. No. 783, ORNL-5002, (1975) 222 pp. 